\title{
UNPREDICTABILITY, TRANSFORMATION, AND THE PEDAGOGICAL ENCOUNTER: REFLECTIONS ON "WHAT IS EFFECTIVE" IN EDUCATION
}

\author{
Aislinn O'Donnell \\ Department of Learning, Society, and Religious Education \\ Mary Immaculate College, University of Limerick
}

\begin{abstract}
Aвstract. In this article, Aislinn O'Donnell offers a set of reflections on the relation between therapy and education. In the first section, she examines criticisms of therapeutic education, mobilizing the example of prison education to highlight the difficulties that arise from imposing prescriptive modes of subjectification and socialization in pedagogy. In the second section, she addresses the relation between therapy and education by focusing on just one element of the experience of education: those moments at which a subject has the potential of becoming significant in the life of a student. An important dimension of the educator's authority involves noticing such moments, fostering the conditions that make them more likely, and engaging in the creative process and practice of deciding how best pedagogically to respond to these moments. In the third section, O'Donnell develops this idea by detailing a philosophical approach and practice that understands "effectiveness" in education as bound to practice, creative responsiveness, and the judgment of the educator in concrete, singular pedagogical situations, rather than construed in terms of generic models of "best practice."
\end{abstract}

\section{INTRODUCTION}

Efforts to redress the perceived failings of an educational system too narrowly focused on the intellect, alongside an increasing interest in emotional intelligence, have led to the extensive introduction of programs in schools in the United Kingdom, the United States, and elsewhere that seek to address social and emotional learning. While I do not directly address these programs in this article, by drawing upon the example of prison education I seek to highlight some of the problems that may arise with the mobilization of a "skills-based" approach that seeks to promote, measure, and assess social and emotional competence in educational settings. ${ }^{1}$ The example of prison education brings to the fore the difficulty of subjecting the space of education to explicitly therapeutic agendas, in particular with respect to the imposition, explicit or implicit, of a pro-forma or predefined subjectivity or self upon the student. ${ }^{2}$ Programs in both prisons and schools tend to focus on performance indicators of behavioral change within a framework of standards and assessment. ${ }^{3}$

My aim in this essay is to offer an understanding of "therapy" in the educational setting that differs from that implicit in those discourses that

1. Christine Winter offered a critique of such initiatives in "School Humanities and the Pursuit of Democracy: Opening Minds and the Humanities Curriculum Project" (paper presented at the conference of the Women in the Philosophy of Education Society of Great Britain, Edinburgh, Scotland, October 2011).

2. Amy Shuffelton, in her essay "A Matter of Friendship: Educational Interventions into Culture and Poverty" (in this issue), outlines the potentially problematic outcomes of ostensibly benevolent forms of cultural intervention.

3. See, for example, the definition of social and emotional learning (SEL) at http://casel.org/. 
appeal to skills and competencies, as these tend to remain too close to "audit models" of education. I draw upon the insights of a number of the contributors to this symposium in an effort to communicate some of the ways in which we might understand education as therapeutic in the sense of having an existential significance for one's life through the relation to a subject, such as philosophy, carpentry, dance, or biology. By mobilizing the example of prison education, I argue with Martin Buber that, paradoxically, it is when the educator has no intention of directly shaping the character of the student that education is more likely to be transformative existentially. ${ }^{4}$ This transformation is precipitated by the experience of an outward focus on, and engagement with, subject matter rather than as a consequence of an effort to work directly on the self. I focus here on just one element of this experience: those moments at which a subject has the potential of becoming meaningful for the student. I consider the role of the educator in noticing these moments and fostering the conditions that make them more likely through creative pedagogical processes and practices.

As Morwenna Griffiths notes, focusing too narrowly upon predictable and foreseeable outcomes, skills, and competencies in educational discourse and policy can occlude significant aspects of practices central to pedagogy and pedagogical relations. ${ }^{5}$ These include the different modalities of thinking that come into play as students engage with subject matter and the ways in which teachers can, through use of judgment and creative responses, support this process. We may have wondered how it is that someone can come to be moved or transformed by an encounter with a subject in such a way that it has enduring existential significance in that person's life. We may also have reflected on the conditions that support the likelihood of this occurring when devising strategies for teaching and learning and determining curricular content. Yet some of the most significant moments in education can arise from chance occurrences. James Williams tells a story of his grandfather who, as a child, became deaf after surgery. ${ }^{6}$ This meant that he was unable to follow his English lessons. In an inspired act, his teacher gave him a collection of William Shakespeare's works to read and asked him to share his learning with the class. This creative pedagogical response instilled in his grandfather and his descendents an abiding love of literature. The educator's

4. Martin Buber, Between Man and Man (London: Kegan Paul, 1947).

5. Morwenna Griffiths, "Critically Adaptive Pedagogical Relations: The Relevance for Education Policy and Practice," in this issue. Unless otherwise noted, subsequent references to Griffiths are to her contribution to this symposium.

6. James Williams, "Apprenticeship Versus Knowledge" (paper presented at the annual conference of the Philosophy of Education Society of Great Britain, Dundee, Scotland, November 2012).

AISLINN O'DONNELL is Lecturer in Philosophy of Education in the Department of Learning, Society, and Religious Education at Mary Immaculate College (University of Limerick), Faculty of Education, South Circular Rd, Limerick, Co. Limerick, Ireland; e-mail < aislinn.odonnell@mic.ul.ie>. Her primary areas of scholarship are philosophy of education, contemporary feminist theory, Spinoza and the Spinozist heritage, and contemporary French philosophy. 
authority is revealed by his or her capacity for singular judgment and pedagogical creativity in responding to opportunities and obstacles. A teacher may be in a position to precipitate such moments, as in the preceding example, but even the simple act of noticing and seeing a sense of possibility in those unpredictable moments (kairos) that arise in classrooms, such as a gleam of insight or a frown crossing a student's face, better positions the teacher to help students to work through a genuine pedagogical encounter with a subject.

Teacher educators who supervise student teachers will readily describe heterogeneous (or homogeneous) experiences of atmospheres of classrooms and schools. ${ }^{7}$ If the students are terrified of their teacher, or exhausted, or hungry, good planning and an excellent curriculum may well not be sufficient to instill a sense of wonder or a delight in discovery. Attentiveness to elements that can contribute to an enriched and sustaining "milieu," attunement to the experience of the "atmosphere" of classes and institutions, and a welcoming disposition may make it more or less likely that such moments will arise and be noticed, but this is an ongoing affair for all teachers as they modulate their teaching at each moment of each day. Here the language of "assemblage," as discussed by Christiane Thompson, is helpful. ${ }^{8}$ An assemblage can be understood as a heterogeneous and dynamic configuration of relations. If we take the example of education, we might think of the relations of natural light, timetables, gestures, texts, high-stakes testing, the attitude of the teacher, images, technology, arrangement of desks, opportunities to speak, poverty, ideas, plants, and so forth. These elements are not "stand-alone" but rather institute a particular set of relations that are lived and experienced as different atmospheres and rhythms within educational spaces. The quality of the lived experience of this milieu or "atmosphere," which includes elements such as the nature of curriculum and pedagogical strategies, makes a difference to the possibility that a pedagogical encounter might arise for a student.

This emphasis on an approach to pedagogical practice that is attuned to its context-specific nature is also found in Griffiths's contribution to this symposium. It offers a different vision of educational practice, one more focused on the singular situation of each lesson than on the operationalization of generic models of best practice. Such an account has much in common with Pádraig Hogan's description of learning environments as venturesome, alive, and conversational. ${ }^{9}$ The experience of precariousness and surprise that may accompany this collective venture is described well by Thompson when, drawing on Roland Barthes, she

\footnotetext{
7. Many will also have been struck by the extent to which the language of control and a fear of the unpredictable haunt the lives of many student teachers (and unfortunately many teachers). See Deborah Britzman, Practice Makes Practice: A Critical Study of Learning to Teach (Albany: State University of New York Press, 2003).

8. Christiane Thompson, "Evaluations and the Forgetfulness of Pedagogical Relations: Remarks on Educational Authority," in this issue. Unless otherwise noted, subsequent references to Thompson are to her contribution to this symposium.

9. Pádraig Hogan, "Cultivating Human Capabilities in Venturesome Learning Environments," in this issue. Unless otherwise noted, subsequent references to Hogan are to his contribution to this symposium.
} 
speaks of how the educator comes to institute a community of inquiry: "For to be a participant I must lose myself in a way as a learner on a learning trajectory.... [The student] is - by speaking - relating to what others have to say on the matter and is, perhaps, even surprised about what she just expressed regarding the matter." It is not that one comes to the classroom unprepared. Rather a steady grasp of pedagogical techniques and detailed understanding of the subject matter enable the teacher both to be creatively responsive to the students' pathways through understanding and to welcome moments of surprise as different ideas, problems, questions, and perspectives emerge through the educational conversation.

In the first part of this essay I examine Kathryn Ecclestone and Dennis Hayes's criticisms of "the therapeutic turn in education," and I am critical of their response. ${ }^{10}$ I provide an analysis of some of the ways in which education proper in prisons is often devalued in favor of correctional forms of education, particularly in North America but also in the UK, indicating some of the pitfalls of an explicitly therapeutic approach to education. In the second and third parts of this essay I offer a consideration of some of the ways in which education can be understood as therapeutic.

\section{What Is the Relation Between Therapy and Education?}

The pervasiveness of the managerial and technocratic language that mobilizes terms such as "auditing," "standardization," "benchmarks," and "performativity" in policymaking, educational research, and educational practice is outlined by a number of the contributors to this symposium. In recent times this technical and procedural orientation has been accompanied, paradoxical as it might seem, by a growing attentiveness to the affective life of students construed in terms of emotional and social competencies or skills. These two tendencies might at first glance seem to indicate different trends in education; however, it is not clear that this is the case when one examines the methodologies mobilized, the modalities of assessment and evaluation, and the presuppositions about the "normal" human subject and citizen underpinning such interventions, as well as the kinds of criteria and outcomes that are deemed to indicate success. We will look at the case of the prison to explore this issue shortly.

In Ecclestone and Hayes's excoriating and polemical critique of "the dangerous rise of therapeutic education," they describe therapeutic practices in a range of institutional settings. Their book outlines some of the reasons why prescriptive programs inaccurately described as "educational" will (and should) be resisted. Here prescription can be understood as pre-scribed: it is already written who you should become. The "pre-" in this case indicates a ready-made a priori self, and the language of prescription connotes a need for treatment by a range of "therapeutic support workers." When standardized assessments gauge levels of emotional and social competence, and when work on the self becomes the

10. Kathryn Ecclestone and Dennis Hayes, The Dangerous Rise of Therapeutic Education (London: Routledge, 2008). This work will be cited in the text as DTE for all subsequent references. 
prime locus of educational practice, this generates, Ecclestone and Hayes argue, a culture of insecurity that seeks to locate vulnerability, pathologizes it, and then identifies a range of interventions by experts to treat this "diminished self." This in turn leads to a dangerous pathologization of mental and affective life and entails an unwarranted intrusion into the most intimate domains of our existence.

According to Ecclestone and Hayes, in therapeutic education the teacher no longer teaches but rather administers a range of behavioral techniques. Subjects and curricula are portrayed as mere vehicles for promoting active citizenry, respect, or empathy. Learning to learn takes precedence over learning something. The rise in these practices arguably constitutes a form of social engineering that legitimates the intrusion of government into the regulation of what was previously the fabric of the private domain of interpersonal norms and relationships. Developing technologies of the self is a longstanding practice of philosophers, but having experts to measure one's progress in achieving a pre-scribed ideal of the self is a considerably different matter.

Unfortunately, Ecclestone and Hayes react to these practices by seeking to erase almost all references to self, relationality, affect, and subjectivity in education. They make bald statements such as the following: "The intellect, of course, is dispassionate: the self may be interested" (DTE, 152); and "It is the rationality and logocentrism that makes us fully human" (DTE, 152). Perhaps most starkly, they assert,

\begin{abstract}
Knowledge can be taught passionately or indifferently by and to people who may be distraught, upset, happy or content. It does not matter. Knowledge, as it were, conquers all. What we are teaching is not touched by the emotions. We argue that there is room for emotion in education only as the passionate pursuit of truth in the sciences and the study of beauty and human emotions in the arts. (DTE, 153)
\end{abstract}

They also state, with some justification, that "obsession with the emotional aspects of the processes of 'good teaching' reinforces an avoidance of questions about what we are teaching" (DTE, 154). In their concluding chapter they propose radical humanism as the philosophy that ought to underpin the practice of education, saying that "radical humanism is essentially a rational philosophy that focuses on the ability of humans to transform the world by making scientific and social progress through reason. We mean reason in all its aspects, the ability to think, argue, plan, design, create and manufacture" (DTE, 162). They conclude by stating, "What makes humanity is ... an education based on cogito ergo sum not sentio ergo sum" (DTE, 164). ${ }^{11}$

In this reaction to some of the practices that purport to develop social and emotional skills, Ecclestone and Hayes seek to determine what is proper to education by defining it in terms of the pursuit of truth and action of the intellect, which in turn require the bracketing of affect, relationality, and subjectivity. I argue

11. The famous Latin phrases cogito ergo sum and sentio ergo sum are commonly translated as "I think, therefore I am" and "I feel, therefore I am," respectively. 
instead that attention to the affective dimensions of education is to be welcomed; however, it is worrying when interventions are oriented toward the attainment of a subjectivity and a self that has been predefined, often implicitly through the reinforcement of a set of procedural norms of self-monitoring, reflection, and interaction. While welcoming a number of Ecclestone and Hayes's criticisms of "therapeutic education," I argue that the problem with therapeutic education lies in its prescriptive and interventionist nature, the modes of evaluation and assessment that it mobilizes, and its penchant for acting on the self directly. This is why I wish to revisit the question of the relation between therapy and education.

\section{The Case of the Prison}

But as soon as my pupils notice that I want to educate their characters I am resisted precisely by those who show most signs of genuine independent character: they will not let themselves be educated, or rather they do not like the idea. ${ }^{12}$

Only the weakest willed take on the self suggested by the state, the clever wear it only as a veil, and the stubborn resist as best they can. ${ }^{13}$

The vexed issue of education for prisoners foregrounds questions about why we educate and what constitutes an educational practice. The reasons for supporting education in penal institutions tend to be framed in terms of recidivism, rehabilitation, and employability, even in liberal settings, and success is gauged by behavioral outcomes. To maintain that education ought to be subordinate to ends such as religious formation, the economy, or even citizenship is nothing new. Discourses about prison education often describe "what works" in terms of noneducational aims, sometimes for the pragmatic reason that the diverging demands of policymakers, other prison personnel, and wider publics mean that education must be justified instrumentally in terms of the benefits accrued to society and the taxpayer. Even Stephen Duguid, a strong supporter of teaching the arts and humanities in prison and the author of a book detailing the success of Simon Fraser University's program in comparison with subsequent explicitly correctional models, ${ }^{14}$ suggests that the European refusal to countenance rehabilitation as an aim of prison education effectively abandons prisoners by assuming that they are capable of undertaking their own reformation. ${ }^{15}$ But if I take it as my task to rehabilitate the prisoner, do I forgo my authority as an educator? If education is subordinated to ends such as these, might it be seen as, or indeed be, a form of manipulation or indoctrination? Can education be based

12. Buber, Between Man and Man, 133.

13. Stephen Duguid, Can Prisons Work? The Prisoner as Object and Subject in Modern Corrections (Toronto: University of Toronto Press, 2000), 200.

14. Stephen Duguid, British Columbia Prison Education Research Project: Final Report (Vancouver, British Columbia: Institute for the Humanities, Simon Fraser University, 1998), 103-114, http://www.sfu.ca/humanities-old/ifeps/report.htm.

15. Duguid, Can Prisons Work? 264. 
upon an ethic of respect for the singular other if all I see is the "criminal"? Indeed, can such practices claim the name of education? What happens if I think I need to produce a particular kind of student as an "outcome" of learning?

Putting aside momentarily whether one ought to seek to justify education on noneducational grounds, such as recidivism, it seems that the policy of relying upon "evidence-based" practice appears to be suspended as programs with such aims gain further ground. The evidence from Simon Fraser University's comprehensive evaluation of the impact of their program on recidivism demonstrated that a liberal arts education was more effective in preventing recidivism for a range of cohorts. Despite this, educational programs are increasingly colonized, or indeed replaced, by a range of correctional education programs offering courses in life skills, communication skills, anger management, and so forth. ${ }^{16}$ In light of such trends, educators may feel a sense of urgency to explain what it is that we do as educators, what constitutes the province of education, and where the line may be drawn between education and therapy.

The idea that there can be found a generic approach to "what works" obscures our understanding of the aims of education, the relation between means and ends in the practice of education, and the complexity of educational landscapes by assuming that we know what education is and that we can identify universalizable criteria that will enable us to evaluate the effectiveness of an educational intervention. Ray Pawson notes,

Evaluation research has its origins in agricultural and medical science. In these fields, the "what works?" question is a relatively simple one, the interventions under scrutiny are (a) singular "treatments"; (b) applied to a well-defined set of "subjects"; (c) targeted at specific "outcomes."17

Pawson is here examining the correlation between educational intervention, designated subjects, and re-offending rates in the prison context, but we also find in education more generally a tendency to deploy a causal, individualized, and asymmetrical account of the relation between the intervention of the teacher and the learning of the student that fails to capture the complexity, relationality, and dynamic responsiveness within the environment, let alone the range of other variables that shape these dynamics from day to day.

Duguid's book illuminates the paradox of education within a coercive and total regime. If education "works" in terms of operating as a successful agent of rehabilitation, then it is likely to be resisted. The educator finds him- or herself in a double bind between a commitment to the value of education and the need to justify that value through reference to noneducational aims, be they

16. Anne Costelloe and Kevin Warner, "Beyond 'Offending Behaviour': The Wider Perspectives of Adult Education and the European Prison Rules" (paper presented at the conference of the European Prison Education Association, Oslo, Norway, September 2005).

17. Ray Pawson, "The Evaluator's Tale," in Prison(er) Education: Stories of Change and Transformation, ed. David Wilson and Anne Reuss (Winchester, England: Waterside Press, 2000), 65. 
security, preventing recidivism, crime prevention, rehabilitation, employment, and, I suggest controversially, measurable improvements in literacy through basic skills programs. Duguid argues that we ought to treat the prisoner as a subject - that is, as a fellow human being - rather than an object, and that by treating him or her as such, the prisoner is more likely to "absorb social and moral values deemed essential to life in a democratic society." 18 His writing displays a consistent strain of ambivalence with respect to the prisoner as subject when he describes the character traits of "typical" prisoners while simultaneously arguing that we ought to suspend a priori judgments about prisoners. Although keen to distinguish education from therapeutic communities and to preserve the space of education as site of experimentation, Duguid sometimes prescribes an identity toward which the prisoner ought be directed, such as the citizen. Such attempts to show how education programs contribute to the kinds of noneducational ends that I mentioned previously arise primarily because education in prison is a precarious endeavor. Yet, Duguid also views the arts and humanities as personally transformative, increasing human beings' capacity for moral imagination and empathy.

Daniel Karpowitz states the case more explicitly when writing about the Bard Prison Initiative (BPI). He says that the educational process ought to be "objective," that is, focused on the objects of study rather than on the prison setting, "the lifeexperiences, ethnicity, or moral and juridical status of the incarcerated students," in no small part because of the kinds of behavioral management strategies deployed in the service of rehabilitation that emphasize individual choice and reward and punishment. ${ }^{19}$ In Karpowitz's view, "the result is an emphasis on teaching concept-critique over and above the goal of 'normalizing' individual behavior." 20

Although Pawson states that the "education-for-education's-sake" argument will not "bring a single further teacher into the prison," he argues, nonetheless, that preserving a space of education that is autonomous of other agendas makes it more likely that these other ends will be served:

The underlying idea [of Simon Fraser University's prison education program], insofar as this was possible behind penitentiary wires, was to imitate the educational provision at Simon Fraser. Tutors got on with their Introduction to North American History, their Creative Writing, their Shakespeare, and so on with ne'er a thought for rehabilitation and certainly no moralizing about crime. ${ }^{21}$

Likewise, Daniel Karpowitz and Max Kenner cite government documents that maintain, "According to the National Institute of Justice Report to the U.S.

18. Duguid, Can Prisons Work? 318.

19. Daniel Karpowitz, "Prison, College, and the Paradox of Punishment," Studies in Law, Politics, and Society 37 (2005): 312.

20. Ibid., 313.

21. Pawson, "The Evaluator's Tale," 70. 
Congress, prison education is far more effective at reducing recidivism than boot camps, shock incarceration, or vocational training. ${ }^{\prime 22}$ While Duguid is critical of the principled refusal by the Council of Europe to appeal to the language of rehabilitation in its "Prison in Education" document, it is arguably the refusal to do so that led to the success of his own program.

Despite superficial affinities between the position outlined by Ecclestone and Hayes and that of Karpowitz, I believe that Karpowitz's analysis of the BPI tells us something important about the necessary function of the subject matter of education (such as texts, concepts, images, questions, and ideas) that communicates well the way in which education can be understood to be transformative. In the case of the BPI, the focus is on texts and tutors deploy a conventional rather than "critical" pedagogy. Karpowitz says, "If there is a field which provides a space of relative discursive equality, it is made up of the texts themselves and the mutual demand of respect for, close attention to, and mastery of those texts." 23 The teacher provides access to this world of "knowledge, imagination, information, and skills which are all seen as the rightful inheritance of each and every student." 24

\section{Unpredictable Pedagogical Encounters}

We never learn from the dictionaries our teachers or our parents lend us. The sign implies in itself a heterogeneity of relation. We will never learn by doing like someone but by doing with someone, who bears no resemblance to what we are learning. ${ }^{25}$

An event does not take place in the world: it opens the world. ${ }^{26}$

The reason for adopting the approach outlined by Karpowitz brings us back once more to the criticisms of therapeutic education. He remarks,

It is my understanding that such embedded or subjective modes are too much in danger of reproducing the individualistic, therapeutic, and correctional modes of the prison establishment.... It is precisely in the encounter and acquisition of authors, texts and contexts beyond and outside of their immediate experience that is, when combined with a care for critical consciousness, an empowering form of education. ${ }^{27}$

Karpowitz's analysis is sensitive to the specific conditions of the prison environment, in particular as regards the "coercive" approaches to producing subjectivity and demands that one expose oneself to others. The problem with

22. Daniel Karpowitz and Max Kenner, Education and Crime Prevention: The Case for Reinstating Pell Grant Eligibility for the Incarcerated (Annandale-on-Hudson, New York: Bard Prison Initiative, 1995), https://www.stcloudstate.edu/continuingstudies/distance/documents/EducationasCrimePrevention TheCaseForReinstatingthePellGrantforOffendersKarpowitzandKenner.pdf.

23. Karpowitz, "Prison, College, and the Paradox of Punishment," 324.

24. Ibid., 325.

25. Gilles Deleuze, Proust and Signs (1964; repr. Minneapolis: University of Minnesota Press, 2000), 22.

26. Henri Maldiney, Penser l'Homme et la Folie [Thinking Man and Madness] (Grenoble, France: Jérôme Millon, 1991), 230 .

27. Karpowitz, "Prison, College, and the Paradox of Punishment," 326. 
therapeutic education is the bluntness of its instruments, its lack of delicacy, and its monolithic understanding of the "good self." It is through the introduction of mediators (such as texts, images, films, and ideas), rather than through direct and explicit work on the self, that subjectivities find the means to compose themselves differently, but the nature of this composition cannot be defined a priori. It also involves consideration of the kinds of relations that can be fostered through the collective venture of learning.

As Maxine Greene notes, "Objections to totalized and decontextualized approaches have brought with them a renewed interest in what is conceived of as situated knowledge and embodied knowledge. ${ }^{\prime 28}$ In Griffiths's essay, we are reminded that the embodied "what" of who we are also matters in education. What I am makes a difference, although it does not overdetermine our relation to education. Moreover, even though our histories and identities make a difference to the atmosphere of our educational milieu, it is not possible to determine in advance what difference they will make. What will matter is the emergent quality and interplay of our relations as a collective, situated within a wider context, as we engage in conversations about philosophy. How this phenomenological experience of collective inquiry is understood will change with site, subject, time, and context.

For example, Thompson comments that she hopes that students in her seminars may come to "forget themselves," by which I think she means to fully engage in the community of collective inquiry about a subject matter. This echoes Alison Assiter's sense that education is not only about imparting a love of subjects, such as philosophy, but is also about creating opportunities for students to engage with a world full of experiences different from their own. ${ }^{29}$ She describes the joy and love of engaging with philosophical ideas collectively. The space then remains for students to interpret these ideas on their own terms. That practice constitutes an ethics of being-with both others and the subject matter.

Resonant with this vein of thinking, both Jean Oury and Gilles Deleuze have suggested that educational contexts need to maintain a sense of heterogeneity in order to sustain interest, participation, and engagement. For Oury, "if we are to have effectiveness, then we must have difference. ${ }^{\prime \prime 30}$ This belief stems from, first, their interest in the conditions that allow for a sense of engagement,

28. Maxine Greene, "Epistemology and Educational Research: The Influence of Recent Approaches to Knowledge," Review of Research in Education 20, no. 1 (1994): 426.

29. Alison Assiter, "Love, Socrates, and Pedagogy," in this issue.

30. David Reggio and Mauricio Novello, "The Hospital Is Ill: An Interview with Jean Oury," Radical Philosophy 143 (2007): 35. Jean Oury forms part of a lesser-known group of pedagogues and psychiatrists working in France among whom we find Jacques Schotte, François Tosquelles, and Fernand Oury. He worked with Tosquelles at Saint Alban during World War II when the most vulnerable in society were targeted by eugenicist policies and struggled against the tendency to homogenize and segregate those who were mentally ill as well as prisoners and other groups. Oury set up La Borde Clinic in Cour-Cheverney in 1953. When Félix Guattari was only fifteen, he met Oury and worked with him at La Borde until Oury's death. 
passion, excitement, and discovery in classes and, second, their awareness of the implications for students of existing in an atmosphere of repetitive dullness. If we reflect upon our institutions, including many schools, hospitals, and prisons, we find as we move between them "the same atmosphere, the same conditions and the same status: the homogeneous and the "ineffective." ${ }^{\prime 31}$ We might contemplate the experience for students and teachers in those classrooms centered on achieving success in high-stakes testing or terminal examinations, which too often focus on rote learning and memorization as the most effective methods for accomplishing this goal. ${ }^{32}$

In this respect, Oury distinguishes between effective in terms of realizing predesignated outcomes (for instance, instructional ends, examination results, or behavioral change) and effective in the existential sense of developing a transformative relation to the self, to others, and to the subject matter. Like Thompson, Oury values surprise and claims that we need to sustain within our institutions the opportunity for unpredictable encounters. I am not suggesting that this is the only element to which we need to attend in teaching, but rather that it is an important element in the pedagogical relation and experience. What follows are some examples, drawn from my experience of teaching in prison settings, of moments that I see as educationally effective and that could not have been readily foreseen. ${ }^{33}$ At certain moments I acted on the judgment that a particular suggestion would make pedagogical sense for that student or that class, and at other moments I simply responded to the ideas presented to me. It is, however, unlikely that I could have determined in advance who would respond in what way to the philosophical material that we were discussing.

One day I had a conversation with a man, a prisoner-student, about how we could develop our shared curriculum. He said that he wanted to read Fyodor Dostoevsky's Crime and Punishment. I asked him why, and he said, "That's all I know." A little while later as we walked together, I said something along the lines of this:

That isn't all you know. You have said that you have tried to preserve a sense of dignity and a sense of self throughout your sentence. Philosophers like the Stoics write about technologies of the self and it seems to me that this is something you have thought about a lot. Have a look at Marcus Aurelius's Meditations.

For a number of reasons, I didn't see this student in class again, but one day, some weeks later, a red envelope was passed to me by another man, also a prisoner. It contained the writings of my student who had acted on my suggestion that he

31. Reggio and Novello, "The Hospital Is Ill: An Interview with Jean Oury," 35.

32. Nel Noddings reminds us that as a teacher one can achieve instructionally, but "if A hates X and his teacher as a result, we have failed educationally. A is not 'better' as a result of our and his efforts." Nel Noddings, Caring: A Feminine Approach to Ethics and Moral Education (Berkeley: University of California Press, 1984), 174.

33. I offer philosophy classes in the high security Portlaoise Prison in the Republic of Ireland to both ordinary and political prisoners, as well as in two organizations that work with people on probation. 
write about the way he had developed technologies of the self through a Stoic lens. This piece took the form of advice to a novice prisoner. The writing was parsed and unsentimental. As I read it, I thought about how impossible it must be to endure existence when one is forced to eliminate any manifest trace of vulnerability. I could neither know nor expect that this man would respond to my suggestion so wholeheartedly and so thoughtfully.

Similarly, in one interview with former political prisoners, I asked a man whether he would have become involved in filmmaking with Jonathan Cummins, an artist and teacher at the prison, had he known what would emerge: a series of archives of the self more akin to love letters than to the confessional mode that has saturated the Internet. ${ }^{34}$ These are now part of an exhibition titled When I Leave These Landings. This man spoke of how producing these archives gave him the chance not to lose time during his imprisonment and, further, how it precluded the possibility of reimagining in the future what the time he spent inside was like and what he was like at that time. He added that he would never have become involved with the project had he known what the outcome would be. In addition, the teacher, Cummins, also could not have known or planned that a set of film documents would be the outcome of this particular educational engagement. That outcome emerged slowly through a pedagogical relation and collaborative practice that the two men maintained for up to a decade.

Another participant in this series of interviews, also a former political prisoner, described his transformation through an initiation into painting:

\begin{abstract}
A number of people got into it - it was a world with no rules. There was no vocabulary, no structure to the language, and there were endless possibilities of what you might be do with it and I think that was what was appealing.... Art is a world of possibilities without being confined. There was no judgment in it. You make art - it was not good or bad - it was just what it was.... I started looking at light and windows and the passing of the day through time, that whole place and whole experience, of how time passes and light passed, time locked up and time contained and all of that. It passes differently at different times.... I would look at the cell window and watch the light come through over the day. Before I would have read and seen time as a time of activity and not as a time of observation.
\end{abstract}

An engagement such as this is sought when cultivating an educative milieu, but such a process requires patience, vigilance, and attention as well as the ability to work with the student in a responsive manner.

Other students in my classes described the experience of doing philosophy together not in terms of their learning but as a shift in horizons, the changing of perspective, the provocation to think, and the opening of the mind. Yet some also remained disengaged, uninterested, and unmoved. When Henri Maldiney says that "no a priori can determine the possibility of an event, or the quality of endurance required, or the transformation which maintains openness, ${ }^{\prime \prime 35}$ he

34. This is part of a series of interviews undertaken between 2010-2012 as part of a review of the National College of Art and Design's art program in Portlaoise Prison from 1986 to 2010. This review will be published in 2013 .

35. Maldiney, Penser l'Homme et la Folie, 235. 
helps us to understand both the unexpected moment, or event, of a pedagogical encounter and the way that the person, the student, may need support to integrate that event into their experience in order to work through it, whether in thought, writing, or painting. The experience of such moments can overcome us because the world does not just change its horizon; it changes fundamentally. This is the pathos of education. Suddenly, I no longer see things in the same way as before, and I may come to love a subject in a manner that transforms my life.

Moments when we can't take hold of or grasp a situation because something exceeds us, opening our world, arise for teachers as well as students. To take an example, during one class a short reflective piece entitled "Descartes' First Meditation: What can be called into doubt" slid silently across the table to my hands. I shall quote from it at some length. It began as follows:

\begin{abstract}
René Descartes (1596-1650) wrote the Meditations of First Philosophy in a first-person narrative voice. However, the use of this first-person narrative voice poses a conundrum for the discerning reader, namely, is the narrator of the Meditations, the "I" into whose shoes the reader is invited to step along the path of knowledge, the one and the same René Descartes. The answer is not explicitly stated. Consequently the first notion the reader should call into doubt is the assumption that the author and narrator are synonymous. Perhaps Descartes wrote the Meditations in the first-person narrative voice of a fictitious seventeenth-century philosopher? Such a proposition could be held up to ridicule. However, it could also be argued in mitigation that the author of a tract whose objective is to instill skeptical doubt as a prelude to the attainment of certain knowledge would not dismiss such a proposition out of hand, and perhaps would even welcome such conjecture. The fact is the reader cannot shed any definitive light upon the identity of the narrator. Thus, before moving on, the skeptical author of this essay has decided - in lieu of such definitive knowledge - that more than three centuries of philosophical convention be cast aside and that the narrator of the Meditations be hereupon referred to in the feminine until certainty pertaining to the narrator's identity can be acquired.
\end{abstract}

After a few sentences, I collapsed in laughter at my realization that I had always read the narrator as gendered as well as at the solemn grandiosity of the prose that mischievously mimicked academic convention. When I had regained some composure, I asked the student what made him write it. "Divillment," he said with a smile. ${ }^{36}$ This moment exemplified sur-prise for me. This kind of encounter or event transforms the atmosphere of the situation. Later that day I read another piece on Descartes and Plato that arrested my breath: "Self-illumination is deceptive. Its rays will blind those you must see as not yet recognizing their exile to the darkness and who themselves must resist being accused of accepting they dwell in the dark."

Reading these texts changes the nature of our relations with one another. Often we don't even discuss the writing; it is handed over, like a gift, and woven into the substance of subsequent conversations. My purpose in giving these examples is to communicate something of their unexpected nature and the need for creative responsiveness on the part of the educator both in cultivating the conditions for such pedagogical encounters as well as in finding the means to work through their significance for all concerned. Perhaps most importantly, my point is to show the 
existential significance of the engagement with the subject matter — be it paint, music, film, or philosophy - that cannot be captured by the language of social and emotional competence, and the ways in which such transformation is not simply a function of will and individual choice but constitutes part of an unending and open-ended pedagogical dynamic through a shared love of, and interest in, subject matter. How then can we begin to cultivate the conditions and the atmosphere that will help to spark this interest and passion?

\section{Atmosphere}

Before man thinks, he feels. ${ }^{37}$

This section is concerned with one central aspect of the pedagogical relation: creating an atmosphere. An important dimension of the role of the educator involves tending to the atmosphere of the educational milieu. As educators, we attend to cultivating sites in which, to quote Buber, "something happens" learning, insight, understanding, discovery, surprise, connection, and so forth. One aspect of the authority of the educator is evidenced by the practical wisdom, or phronesis, whereby he or she senses the unpredictable moments (kairos) that emerge through the pedagogical encounter, and then works with a student to find ways to endure and pursue the consequences of this event in a manner that supports transformation. The ephemeral nature of such moments means that they may dissipate quickly. Opening to an unfamiliar world of experience may even precipitate a crisis if such experiences are not integrated into the life of the student. ${ }^{38}$ The educator acts in response, perhaps by raising questions such as "Could you think about ...?" or "Would you write about ...?" Responsiveness and action in such instances require an abductive logic that perceives the importance of such chance moments. This is one of the ways in which educators' authority is embodied and effective.

Oury argues, "if we want to be effective, we have to favor that which is of the order of the encounter." 39 One cannot know when something will happen, when an idea will take hold, at what moment the imagination will be seized by or an affinity found with a philosopher long dead, or even when a sense of a new world opening will be felt. Such encounters are of the order of tuché, or chance, and they can only occur for educators and students who have become welcoming and receptive to what arises. In this respect, the language of opening and undergoing is more helpful than that of mastery and accomplishment.

When Karpowitz describes the BPI approach to education as "objective," he means that it opens people to the rich inheritance of our world. It gives access to

37. Erwin Straus, quoted by Jean Oury in Reggio and Novello, "The Hospital Is Ill: An Interview with Jean Oury," 43.

38. For a discussion of psychoanalysis, affect, authority, and education, see Zdenko Kodelja, "Authority, the Autonomy of the University, and Neoliberal Politics," in this issue.

39. Jean Oury, "Le pré-pathique et le tailleur de Pierre" [The Pre-pathic and the Stonemason], Chimères, Les enjeux du sensible no. 40 (automne 2000): 4. 
something new, with all the thrill of that discovery. We cannot forecast which student will come to be interested in which subject or when that will happen; yet, despite that uncertainty, as educators we strive to continue to create the conditions of possibility for a real engagement with our subject. The difficulty with "best practice models" is that they impose themselves without sensitivity to the existing milieu in all its complexity. No a priori model can program a solution to the "problem" of education because the educational milieu is composed of a complex array of relations and varying temporalities of engagement. With respect to the pedagogical relation, this demands of the teacher not the implementation of a set of procedural guidelines, but what Aristotle called phronesis.

As a teacher, I must come to sense at what moment I need to change my posture, my eyes, and my voice, mediating the space in order to preclude a situation from sparking into conflict (rather than dissensus), just as I must try to sense at what moment something has shifted for someone within a class, when I need to remain silent or when we need to collectively pursue an alternative line of inquiry. ${ }^{40}$ Oury calls this being sensitive (sensible) to the unusual and describes it, following Charles Sanders Peirce, as abductive logic. An effective moment is often evidenced by the small detail or change that one notices as someone falls silent and her face registers that she is deep in thought. Alternatively, it might manifest itself in sudden movement, as in the case of a young man in one of my prison classes who literally leapt from his seat on first encountering Sigmund Freud's concept of the unconscious, when he began to imagine his conscious existence as simply the tip of an iceberg of the self.

Oury bemoans the "technocratic simplism" that he describes as "the culture of bureaucratic requirements and administrative measures developed under the mask of pseudo-scientific progress." He says, "I have constantly struggled against technocratic simplism which, paradoxically, is often presented in very complicated formulae." ${ }^{41}$ In such cases, managerial nonpractitioners occupy themselves with issues that Oury sees as not only trivial but disruptive, such as asking the staff in an institution to fill in forms about how they have spent their time. François Tosquelles called this tendency the bureaucratization of thought; it equates that which is different, it strives for homogeneity, and, according to Tosquelles, it is dictatorial. ${ }^{42}$

Some of Oury's primary complaints regarding these tendencies are that the approach of administrative thought does not grasp what is effective in therapeutic or educational settings, that the temporality of target setting does not accord with the temporality of existence, that administrative thought is indifferent to

40. Jacques Pain draws on the concept of the pathic as developed by Oury and Maldiney to address the issue of violence in classrooms. Jacques Pain, L'école et ses violences [Violence and the School] (Paris: Economica/Anthropos, 2006).

41. Reggio and Novello, "The Hospital Is Ill: An Interview with Jean Oury," 34.

42. François Tosquelles, Cours aux éducateurs [A Course for Educators] (Nîmes, France: Champs Social, 2003). 
local conditions, and that it attempts to eliminate chance and unpredictability, the motor of education and therapy. An example of what is truly effective in a therapeutic setting, he says, is the moment when a young woman, after fifteen years of work with a team, smiles for the first time. He acknowledges that a manager will probably see this as trivial and as a waste of resources, yet the team will understand its significance in her life. He states, "To reach the simple, the fact of being-here, the fact of saying 'hello,' of performing a very simple diagnostic, we need to traverse an enormous complexity. ${ }^{\prime 43}$ Seemingly insignificant moments and gestures can change the atmosphere of the space.

Oury argues that the question of milieu is as vital in education as it is in therapy. While Thompson speaks of "being-with" as a community of inquiry, Oury invokes the substantive "with" (l'avec) to communicate the quality of an atmosphere that encompasses relations beyond the interpersonal. This extends our analysis beyond the pedagogical relation to the "architectonic - the totality of relations, roles, functions and people that defines the site where something happens - [which] is based upon heterogeneity rather than homogeneity!"44 As described earlier, homogeneity is found in those institutional settings that have the same olor, smell (or flavor for Hogan), as we move from one to another. An environment such as the prison tends to permit little heterogeneity. Nor do many workplaces. Or schools. A central task of educators is to engage in what Oury calls a non-deductive ontology that seeks to institute non-preexistent relations, such as an encounter with poetry for the first time or a change in working relations whereby people take on roles that are not prescribed (for example, a nurse cooking). This is akin to working a terrain with mulch or manure in order to create the conditions for the emergence of a pedagogical encounter, the timing of which remains unpredictable, while bearing in mind that what will move one person will have no effect on another.

Oury calls this "working the invisible" because it cannot be captured by preconceived models and requires that the psychiatrist or pedagogue be constantly responsive to the complex interplay of relations. While different elements may be manifest - a lesson note, curricular content, the physical spaces of the institution - the relations among them are invisible, though real. ${ }^{45} \mathrm{He}$ draws upon two images to illustrate this work of the invisible. The first is one of sweeping clean the space, ridding it of prejudgments, clichés, and ready-made ideas about "what works." Rather than focusing on the individual learner or teacher in abstraction from context, this process requires reorienting attention toward the quality of the lived, relational space of the institution. Oury says that just as asepsis in hospitals eliminated pathogens, making possible the practice of medicine, other institutions need to create the conditions through which they can become less toxic.

43. Reggio and Novello, "The Hospital Is Ill: An Interview with Jean Oury," 34.

44. Ibid.

45. See William James's writings on radical empiricism, as he argued that external relations are as real as their terms. 
The second image is of building bridges where they did not exist before, that is, of instituting relations - for instance, arranging an encounter with poetry for someone who has always been involved in manual labor, or with art as in the examples discussed in the preceding section. Oury remarks, "[Tosquelles] often said that the milieu needed to be heterogeneous, even the educational milieu of children. He made it clear that for things to be alive, for there to be exchanges, groups, inter-groups, initiatives, chance and encounters, there must be heterogeneity." He adds that Fernand Deligny maintained that

to harness an approach enabling these people [dissident minorities and marginalized communities] to remain even slightly interested in something, it was necessary to constitute an unexpected heterogeneous environment, for objects as much as spaces and different people. This was one of the essential conditions that guaranteed the effectiveness of the milieu. ${ }^{46}$

Maldiney and Oury constantly return to the idea of "rhythmos" to communicate the sense of movement and dynamism of different atmospheres.

The experience of education is here described in terms of opening, receptivity, and undergoing - the pathei mathos of Aeschylus - rather than competence, activity, or mastery. Pathei mathos is often translated as "learning through suffering," though in Oury's work its sense is closer to "wisdom arises through undergoing." The atmosphere of education may help to provide the conditions for me to open myself to an encounter that will open my world. Different atmospheres offer different possibilities for receptivity, and the "between" of relations gives atmospheres their flavors - even though we cannot perceive or pin down an atmosphere, we sense it and it is as real as the books before me on my desk.

\section{Conclusion}

What makes an atmosphere effective in education is not susceptible to being captured by a generic model; however, we can be certain that where we find a deadening homogeneity, education will be ineffective. Education requires a heterogeneous milieu, but what will create this heterogeneity cannot be prescribed in advance. The atmosphere of education supports (or destroys) the capacity to receive the unpredictable and to invite surprise, allowing us as teachers and students to undergo the event of a pedagogical encounter. Cultivating the disposition to welcome and take care of the singularity of the other helps to conserve such an atmosphere. As educational practitioners, part of our role is to prepare this invisible terrain in order to facilitate the possibility of an event or an encounter that will lead to transformation. Although the image of the educator as gardener is familiar to any of us who work in teacher education, Oury reconceptualizes this figure as he describes the mulch, compost, and muck of this invisible domain that we as educators constantly work with in our everyday engagement with students. The composition of this invisible domain extends to relations and forces beyond the student-teacher relation, which is why, for Oury, so much that is important happens outside the bounds of the regulated

46. Reggio and Novello, "The Hospital Is Ill: An Interview with Jean Oury," 34. 
space of therapy or education - in the passages, the margins, the surroundings. In emphasizing the "entours," the ambience, the Stimmung, we are led beyond designated spaces for teaching and learning, or for therapy, to the lived experience of institutions themselves. The authority of the educator comes into play as he or she works to create an alive, welcoming atmosphere, attuning him- or herself to sense those unforeseeable and unpredictable moments (kairos) that may constitute a pedagogical encounter for an individual student, while supporting the student in pursuing the implications of such a pedagogical event.

In this essay, I have examined some of the criticisms of a therapeutic turn in education, with particular focus on the example of prison education, and I have questioned approaches to social and emotional learning that favor predictable outcomes and standardization while prescribing the character of the desirable "self." Rather, I suggest that the therapeutic potential of education stems from attending to the ways in which a pedagogical encounter that develops one's love of a subject can be existentially transformative. An important element of teachers' authority involves developing processes, materials, questions, practices, and dispositions that make such encounters more likely. 